\title{
Treatment and Preventive Measures for Hepatopathies of Productive Animals
}

\author{
Klavdiya A, SIDOROVA ${ }^{1 *}$, Ekaterina P. KRASNOLOBOVA ${ }^{1}$, Yuriy A. DRABOVICH ${ }^{1}$, \\ Oksana V. KOCHETOVA ${ }^{2}$, and Natalya A. TATARNIKOVA ${ }^{3}$ \\ ${ }^{1}$ Northern Trans-Ural State Agricultural University, Tyumen, Russian Federation \\ ${ }^{2}$ Perm Institute of the Federal Penitentiary Service of Russia, Perm, Russian Federation \\ ${ }^{3}$ Perm State Agro-Technological University, Perm, Russian Federation \\ *Correspondence: sidorova@gausz.ru
}

\begin{abstract}
A large source for increasing the production of livestock products is a comprehensive reduction in animals' morbidity and mortality caused by noncommunicable diseases, among which lesions of the gastrointestinal tract and liver occupy a large proportion. The aim of the research was to study the effect of the composition of medicinal substances on the functional state of the liver. During the research, the following combinations of medicines were used: 1 . - the use of vitamin preparations that cause an increase in the antitoxic function of the liver, accelerate reparative processes; 2 . - the use of metabolites that cause increased energy metabolism in the liver. In order to clarify the effect of treatment on the functional state of the liver, 3 groups of adult ewes of the Edilbay breed at the age of 3 years were selected according to the principle of analogues of 10 heads in each group. The treatment was carried out in experimental groups of ewes from January to February. Blood was tested twice - before and after the treatment. According to the results of the studies, it was found that the treatment had a beneficial effect on the biochemical and morphological parameters of the blood, on the general condition of the animals; functional state of the liver returned to normal in groups of experimental animals.
\end{abstract}

Keywords: sheep, treatment, preventive measures, liver, functional state.

\section{Introduction}

Non-communicable diseases are widespread in sheep farms, which cause great economic damage to farms, as they cause a decrease in the productivity and reproductive ability of animals and make farms incur additional costs for treatment, which ultimately leads to an increase in the cost of livestock products and a decrease in production profitability [1, p. $85 ; 2$, p. $402 ; 3$, p. 127]. A successful struggle for reduction animal morbidity rate is possible only on the basis of cost-effective veterinary measures. Carrying out economic calculations makes it possible for veterinarians and scientists to assess objectively the value of the applied preventive measures and then recommend them for implementation [4, p. 2136; 5, p. 43; 6, p. 712].

A large source for increasing the production of livestock products is a comprehensive reduction in animals' morbidity and mortality caused by non-communicable diseases, 
among which a large proportion is the damage of the gastrointestinal tract and liver. The problem of hepatology of farm animals is one of the poorly developed in clinical veterinary medicine Degenerative changes in the liver parenchyma are associated with the fact that an animal organism is often subjected to exogenous and endogenous intoxications due to violation of feeding and maintenance conditions, especially during the period of maximum stress of all body functions.

The anatomical proximity of the liver to other organs of the digestive system, especially blood supply, blood flow to the liver from all unpaired organs of the abdominal cavity, the close connection of the vessels of the lymphatic system, bile ducts - all this determines the frequency of secondary liver damage. Therefore, at present, the development of means for the prevention and correction of the morpho-functional state of the liver is relevant for livestock breeding [7, p. 861; 8, p. 490].

Therefore, the aim of this research was to study the effect of the composition of medicinal substances on the functional state of the liver.

Preventive and curative measures contributing to the restoration of the liver functional state are poorly developed, especially taking into account significant deviations in the structural and functional state of the liver, in immune and humoral status that the animals possessed. Therefore, during the research, the following combinations of medical substances were used: 1 . - use of vitamin preparations causing an increase in the antitoxic function of the liver and acceleration of reparative processes; 2. - use of metabolites that cause increased liver energy metabolism [9, p. 73].

\section{Materials and Methods}

In order to clarify the effect of treatment on the functional state of the liver, there were selected 3 groups of Edilbay ewes.

Animals of the first (experimental), second (experimental) and third (control) groups had sharp functional deviations of the liver. The diagnosis was made on the basis of clinical and biochemical studies, as well as histological examination of biopsy material.

A liver biopsy was performed with the needle described by S.I. Nikov (1965). The intercostal space of the 11th or 12th ribs (area of hepatic dullness), the coat was cut off and the skin was disinfected with tincture of iodine. A needle with a mandrin was inserted through a small wound anteriorly, downward and to the left, focusing on the left olecranon. After puncture of the abdominal wall, the mandrin was removed. Overcoming some resistance (a sign of getting into the liver), the needle was inserted to a depth of about $2 \mathrm{~cm}$; the needle was rotated around the longitudinal axis, and then quickly removed from the abdominal cavity. A mandril cylinder removed the fixative fluid from the liver tissue, after which the manipulation was repeated again. The material was fixed in a $10 \%$ formalin solution and Cornoy's fluid. Histological processing of the obtained samples was carried out with paraffin blocks and on a freezing microtome. To detect glycogen content according to the Shabadash's method, the sections were stained with hematoxylineosine, Sudan-3. Liver tests from five healthy and nine sick sheep were subjected to the pathohistological study.

The treatment was carried out in experimental groups of ewes from January to February. Blood was taken twice - before and after the treatment. 
Sheep with a violation of the functional state of the liver was treated according to 2 schemes: 1 ) by using a metabolite (a mixture of succinate and sodium citrate in a ratio of $3: 1) 15 \mathrm{mg} / \mathrm{kg}$ orally once a day for 10 days; 2) the simultaneous administration of trivitamine (vitamins A - 150 thous. M.E., D3 - 200 thous. M.E. and E - $100 \mathrm{mg}$ ) in an amount of $10 \mathrm{ml}$ with $20 \%$ solution of ascorbic acid $5 \mathrm{ml}$ intramuscularly twice a month, and $100 \mathrm{mg}$ of cocarboxylase intramuscularly for 4 days in a row. The treatment was carried out for 2 months.

To study the effect of the composition of medicinal substances on the functional state of the liver, 3 groups of ewes of the Edilbay breed at the age of 3 years were selected according to the principle of analogues of 10 animals in each group.

\section{Results}

Certain enzyme systems are involved in the formation and course of pathological processes in the liver. Acting on the enzyme systems of the animal organism with medical substances, it is possible to change the course of enzymatic processes in the desired optimal direction. Among these substances include succinic acid, citric acid and their salts.

Studies in the field of medicine prove the effectiveness of the use of succinic acid in the treatment and prevention of a number of diseases in adults and children. A positive effect of co-carboxylase on the body is associated with activation of the carboxylase enzyme, as well as a number of complex enzymatic oxidative decarboxylation systems. Co-carboxylase influences favorably on cardiac weakness, with impaired carbohydrate and protein metabolism. The complex of vitamin preparations normalizes redox and other metabolic processes, increases the body's resistance. Therefore, in order to restore the functional state of the liver of animals, a mixture of succinate and sodium citrate was used in a ratio of 3:1.

When conducting histological examination in sections obtained by biopsy of the liver of clinically healthy sheep, the preservation of the structure of the liver tissue was noted.

In animals with a violation of the functional state of the liver (according to biochemical studies), violations of the frame structure of the liver tissue, hyperemia of the vessels with slight lymphoid infiltration was established. The nuclei are swollen, displaced to the periphery of the cells, in some liver cells the nuclei are pyknotized and the cytoplasm has acquired a granular appearance, the presence of granular and fatty degeneration is noted.

The treatment was carried out in experimental groups of ewes from January to February. Blood was taken twice - before and after the treatment.

The first group (experimental) animals used the treatment regimen I; the second group (experimental) used the treatment regimen II.

Before the treatment, the number of erythrocytes and hemoglobin in animals was almost the same in all groups, after treatment (Figure 1,2) in the first group - the number of red blood cells increases by $26 \%$, in the second group - by $32 \%$. The hemoglobin level in the first experimental group rises by $24.7 \%$, in the second group - by $31.5 \%$. These data indicate a favorable effect of the treatment on erythropoiesis and hematopoiesis. 
Therefore, in experimental groups of animals, metabolic processes are activated in connection with better oxygenation of cells and tissues.

The number of leukocytes before the treatment is slightly different in all the studied groups. After treatment, as can be seen from Figure 1, in the first group their level decreases by $9.5 \%$, in the second group - by $10 \%$, which indicates a decrease in inflammatory reactions in the body, and normalization of the immune status.

After applying the treatment, the metabolic functions of the liver are restored, as evidenced by an increase in blood cholesterol - the first group to $3.04 \mathrm{mmol} / \mathrm{L} \mathrm{(20 \% )}$ and the second group to $3.03 \mathrm{mmol} / \mathrm{L}(20.2 \%)$ (Figure 1).

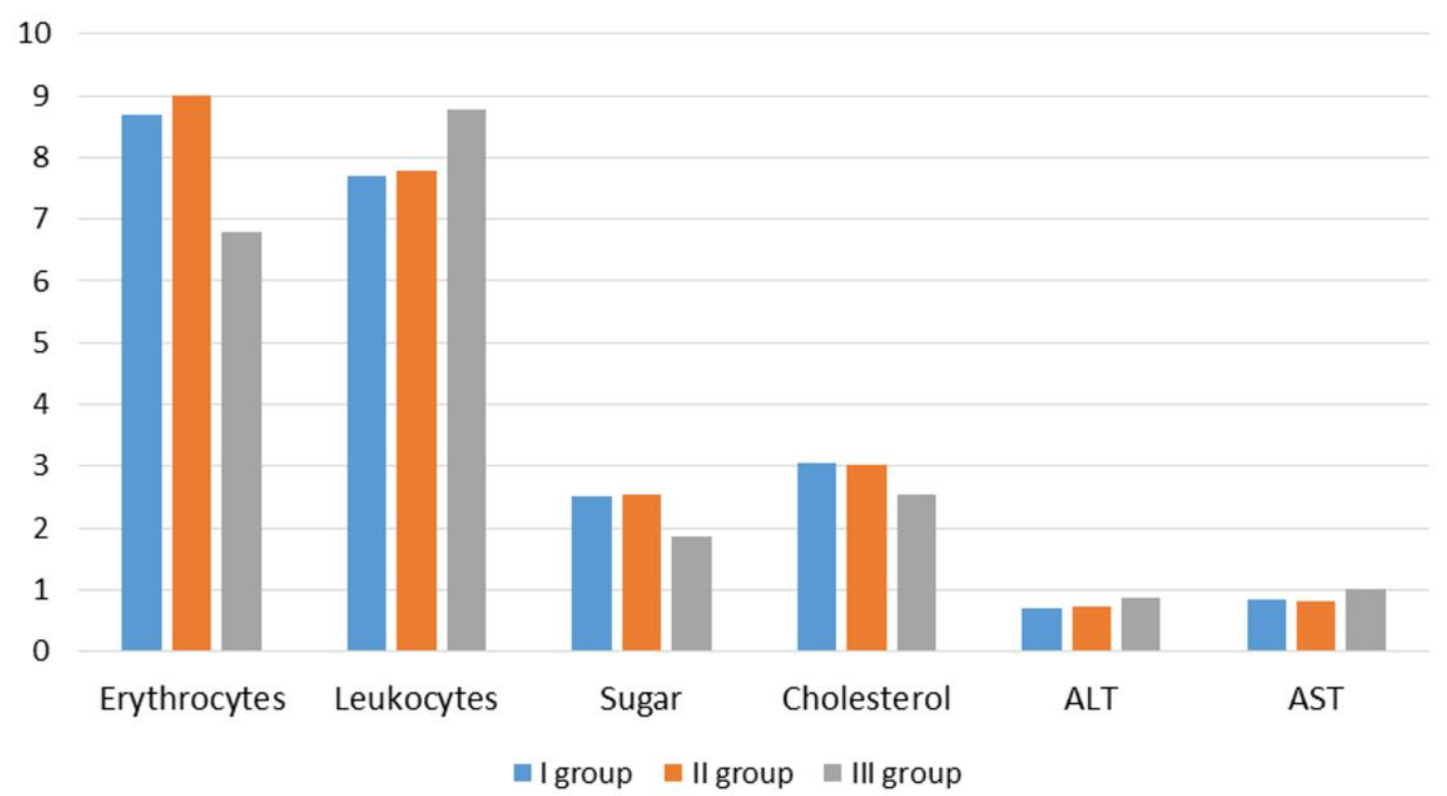

Figure 1. Some indicators of sheep blood after treatment

After the treatment, the sugar level in the experimental groups of animals increased to 2.52 and $2.55 \mathrm{mmol} / \mathrm{l}$ (Figure 1). An increase in blood glucose indicates an increase in the activity of the glucokinase enzyme, which, in turn, helps to provide the body with metabolites for the biosynthesis of fatty acids and glycerol. In addition to the decomposition of glucose in the liver, its formation occurs due to gluconeogenesis or as a result of the breakdown of glycogen.

The main processes of protein metabolism occur in the liver. Most plasma proteins, as well as proteins of the hemostatic system, are synthesized in the liver. The development of patho-morphological processes in the liver negatively affects the protein metabolism in the body, the protein metabolism in hepatocytes is disrupted, which leads to a violation of the protein composition of blood plasma and most often there is a decrease in total protein. Therefore, a criterion that allows judging the state of the protein-forming function of the liver is serum protein, its level, ratio, colloid resistance [10, p. 256].

The level of total protein in group I animals increased by $15.7 \%$, and in group II - by $14.5 \%$, in the control group of animals there is a slight decrease in the amount of total protein (4\%) (Figure 2). 


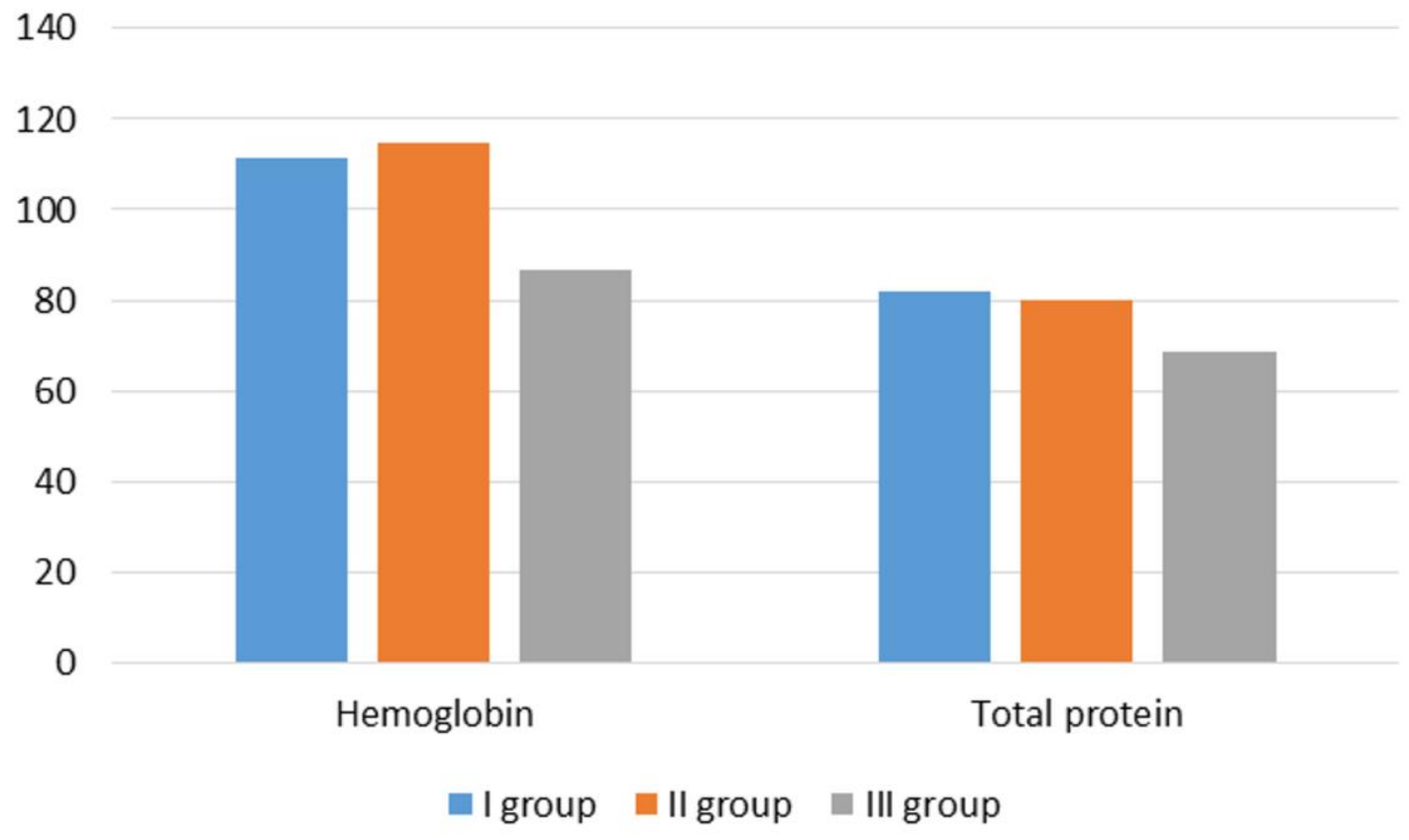

Figure 2. The level of hemoglobin and total protein in the blood of sheep after treatment

Among the group of transferases, the most sensitive enzymes in hepatopathies are alanine aminotransferase (ALT) and aspartate aminotransferase (AST).

A blood test found that the level of ALT decreased in experimental animals by $11 \%$ (group I) and 10\% (group II), AST - by 10.5\% (group I) and 15\% (group II) (Figure 1).

\section{Discussion}

Due to some anatomical and biochemical characteristics, liver is involved in the regulation of almost all metabolic prosesses. Its main function is regulatory and homeostatic, which consists in maintaining a constant blood level of components for carbohydrate, protein, lipid and other exchanges. Therefore, in pathological conditions, the chemical composition of the liver changes significantly. This is reflected in a change in the biochemical composition of the blood. According to the results of the studies, it can be concluded that the treatment had a beneficial effect on the biochemical and morphological parameters of the blood, on the general condition of the animals; the functional state of the liver returned to normal in groups I and II of the experimental animals.

\section{Conclusion}

The studied composition of medicinal substances (sodium succinate and sodium citrate in a 3:1 mixture), trivitamin, a solution of ascorbic acid and co-carboxylase helps to normalize metabolic processes in animals, restore the impaired functional state of the liver and prevent this pathology. In addition, this treatment regimen is quite simple to use and restoration of liver tissue occurs in a shorter period of time. 


\section{References}

(1) Sidorova, K. A.; Pashayan, S. A.; Kalashnikova, M. V.; Cheremenina, N. A. Functional Features of Farm Animals. International Journal of Applied and Fundamental Research 2014, 6, 84-85.

(2) Kozlova, S. V.; Krasnolobova, E. P.; Veremeeva, S. A. Analysis of the Etiological Structure of Subclinical Mastitis in the South of the Tyumen Region. In International scientific and practical conference "AgroSMART - Smart solutions for agriculture" (AgroSMART 2018); Atlantis Press: Tyumen, Russia, 2018. https://doi.org/10.2991/agrosmart-18.2018.75.

(3) Satkeeva, A. B. Effects on Productivity, Physiology and Biochemistry from Introducing Zeolite Sourced from Lyulinskoye Deposit into Animal Diet (in Russian). In International scientific and practical conference "AgroSMART - Smart solutions for agriculture" (AgroSMART 2018); Atlantis Press: Tyumen, Russia, 2018. https://doi.org/10.2991/agrosmart-18.2018.117.

(4) Sintiurev, O. K.; Glazunova, L. A.; Plakhotnik, A. V.; Glazunov, I. V.; Dragich, O. A.; Sidorova, K. A. Sintiurev Effectiveness of Surgical. Treatment of the Left-Sided Displacement of the Abomasum in Cows and First Heifers in Trans-Urals. Research Journal of Pharmaceutical, Biological and Chemical Sciences 2019, 10 (1), 21362140.

(5) Sidorova, C. A.; Maslova, E. N.; Cheremenina, N. A.; Domatsky, V. N.; Glazunova, L. A. State of the Body of Rabbits Suffering from Psoroptosis Receiving Sel-Plex. Biology and Medicine 2014, 6 (3), BM-043-14.

(6) Sidorova, K. A.; Dragich, O. A.; Ermolina, S. A.; Kochetova, O. V.; Balabanova, O. A. Ecological and Physiological Assessment of Animal Anesthesia Methods. KnE Life Sciences. Series: International Scientific and Practical Conference "AgroSMART Smart Solutions for Agriculture" 2019, 4 (14), 712-718. https://doi.org/10.18502/kls.v4i14.5667.

(7) Skipin, L.; Gaevaya, E.; Zaharova, E.; Petukhova, V.; Sidorova, K. Biogeochemistry of Heavy Metals in Trophic Chain in Terms of the South of Tumen Region. Procedia Engineering 2016, 165, 860-868. https://doi.org/10.1016/j.proeng.2016.11.785.

(8) Maslova, E. N. Spreading of Sarcoptes Scabiei, as Psoroptes Cuniculi on Rabbits and Otodectes Cynotis on Domestic Carnivores (in Russian). In International scientific and practical conference "AgroSMART - Smart solutions for agriculture" (AgroSMART 2018); Atlantis Press: Tyumen, Russia, 2018. https://doi.org/10.2991/agrosmart-18.2018.92.

(9) Sidorova, K. A.; Dragic, O. A.; Ermolina, S. A.; Kochetova, O. V.; Ryabova, N. N. Adaptive Features of the Sheep Body in Conditions of Technogenesis (in Russian). Natural and Technical Sciences 2019, 3, 71-76.

(10) Sidorova, K. A.; Cheremenina, N. A.; Krasnolobova, E. P. Informativeness of Laboratory Indicators in Case of Hepatopathy of Animals (in Russian). Bulletin of the Orenburg State Agrarian University 2018, 4 (72), 254-257. 


\section{Information about Authors}

Klavdiya Aleksandrovna SiDOROVA: D.Sc. in Biology, Professor, Head of Anatomy and Physiology Department, Northern Trans-Ural State Agricultural University; 7 Republiki Str., Tyumen, 625000, Russia; e-mail: sidorova@gausz.ru.

Ekaterina Pavlovna KRASNOLOBOVA: Ph.D. in Hystory, Associate Professor, Department of Anatomy and Physiology, Northern Trans-Ural State Agricultural University; 7 Republiki Str., Tyumen, 625000, Russia; e-mail: e_krasnolobova@mail.ru.

Yuriy Aleksandrovich DRABOViCH: Postgraduate student Northern Trans-Ural State Agricultural University; 7 Republiki Str., Tyumen, 625000, Russia; e-mail: IBVM.veterinarya@yandex.ru.

Oksana Valerievna KOCHETOVA: D.Sc. in Economics, Associate Professor, Perm Institute of the Federal Penitentiary Service of Russia; 125 Karpinskiy Str., Perm, 614012, Russia; e-mail: kochetovaox@yandex.ru.

Natalya Aleksandrovna TATARNiKOVA: D.Sc. in Economics, Professor, Head of Infectious Diseases Department, Perm State Agro-Technological University; 23 Petropavlovskaya Str., Perm, 614990, Russia; e-mail: tatarnikova.n.a@yandex.ru. 